\title{
MEDICAL WASTE MANAGEMENT AT DIFFERENT HOSPITALS OF ANAND AND NEARBY AREAS
}

\author{
Urvashi Mishra*, Sarjoo Patel*, Kushan Shah** \\ * The Maharaja Sayajirao University of Baroda, Faculty of Family and Community Sciences, Department of \\ Family and Community Resource Management, Vadodara, Gujarat, India \\ ** Ashok and Rita Patel Institute of Integrated Study and Research in Biotechnology and Allied Sciences, \\ New Vallabh Vidyanagar, Gujarat, India
}

corresponding author: Urvashi Mishra, e-mail: urva_mishra@yahoo.com

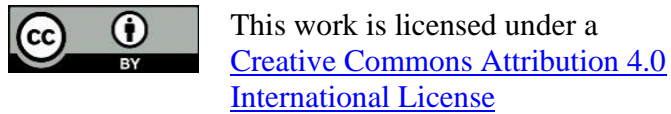

$\underline{\text { International License }}$

\author{
Professional paper \\ Received: March 16 ${ }^{\text {th }}, 2020$ \\ Accepted: May $17^{\text {th }}, 2020$ \\ HAE-1941 \\ https://doi.org/10.33765/thate.11.2.2
}

\begin{abstract}
The increased number of hospitals with rising number of beds generate about 1.5 to $2 \mathrm{~kg}$ waste per day and per bed. This gives an insight about the volumes of waste generated from the government and private sector hospitals per day. Therefore, the hospital waste management is of utmost importance in the present public health scenario, where the occurrence and recurrence of the infectious diseases is a major public threat. The objective of this research was to find out how hospitals can benefit from improving medical waste management practices. In the questionnaire, survey questions were formulated for gathering data. The questionnaire was designed in such a way that it can provide general information about the hospital staff along with their knowledge about the medical waste and their concern regarding the waste disposal-training program. It was found that the importance was being laid on proper waste disposal only and much less focus was given on waste minimization and recycling of the waste. The study has found that the city can benefit both environmentally and economically by improving the medical waste management at different hospitals.
\end{abstract}

Keywords: medical waste, hospitals, waste management practices

\section{INTRODUCTION}

The ever increasing contagious medical waste has drawn an attention in the field of health care system over the years. The health of the public, patients and professionals is affected by poor waste management practices [1]. Apart from this, poor waste management also contributes to the degradation of environment.
Now, years later, this has turned into a global humanitarian issue because of improper handling of the waste. In developing countries, the hospital waste disposal has neither a proper process nor guidelines provided by the government, leaving it as a phenomenal problem of immediate concern. The increased number of hospitals with rising number of beds generate about 1.5 to $2 \mathrm{~kg}$ waste per day 
and per bed. This gives an insight into the volumes of waste generated from the government and private sector hospitals per day. Therefore, the hospital waste management is of utmost importance in the present public health scenario, where the occurrence and recurrence of the infectious diseases is a major public threat [2].

Currently, Anand is a small city which is expanding at a very fast rate. There are many small-scale hospitals in Anand and nearby areas, which generate approximately 2 $\mathrm{kg} / \mathrm{bed} /$ day of medical waste. Hence it becomes quite necessary for proper waste disposal. Also, at the rate at which Anand is growing, it will soon become a megacity like Ahmedabad and also much more multispecialty hospitals will be established to improve the medical facilities given to the people. This will also add to the currently generated waste. Hence it is necessary to take precautions for right now so that no problems arise in future. In order to achieve significant and long term reduction in carbon foot prints, the organization should first assess the various opportunities for carbon reduction and should develop a structured master plan for the same [3]. In regard to issues in waste management, higher generation rates of medical waste due to improper segregation and waste disposal are the key areas of concern. Waste transportation and final disposal is the area of concern in medical waste management. Hence a study on the medical waste management is essential to provide a structured master plan to reduce carbon emissions and achieve sustainability.

\section{Objectives}

The overall objective of this research is to perform a study on the current medical waste management at hospitals and aims to find out how hospital can benefit from improving medical waste management practices.

\section{Aims}

- To analyse the current medical waste management legislations, policies, and practices at different hospitals.

- To understand the perception of staff at different hospitals towards the medical waste management and to analyse how it affects the waste generation at hospitals.

- To find out the amount of greenhouse gases (GHG) emitted in transportation of waste from hospitals to waste disposal sites.

- To find out the cost effectiveness of setting up a waste disposal plant within the vicinity of the city.

\section{METHODOLOGY}

The methods chosen specifically relate to the aims and objectives of the research study. It is shown below in Table 1 .

Table 1. Methods adopted for the study

\begin{tabular}{|c|c|c|}
\hline Objectives & Methods & Output \\
\hline $\begin{array}{c}\text { To collect } \\
\text { primary data } \\
\text { and } \\
\text { understand } \\
\text { the current } \\
\text { waste } \\
\text { management } \\
\text { policies and } \\
\text { practices at } \\
\text { different } \\
\text { hospitals. }\end{array}$ & $\begin{array}{c}\text { - Site visits/ } \\
\text { participant observation } \\
\text { in Anand and nearby } \\
\text { areas. } \\
\text { - Interview with } \\
\text { different people } \\
\text { associated with } \\
\text { medical waste } \\
\text { disposal. }\end{array}$ & $\begin{array}{c}\text { - Current waste } \\
\text { management policy. } \\
\text { - The waste generation } \\
\text { data. } \\
\text { - Information about } \\
\text { medical waste } \\
\text { disposal. }\end{array}$ \\
\hline $\begin{array}{l}\text { To } \\
\text { understand } \\
\text { the perception } \\
\text { of staff } \\
\text { towards } \\
\text { medical waste } \\
\text { management. }\end{array}$ & $\begin{array}{c}\text { - Participant } \\
\text { observation. } \\
\text { - Quantitative survey. } \\
\text { - t-test }\end{array}$ & $\begin{array}{c}\text { - Employees' interest } \\
\text { towards medical waste } \\
\text { management. } \\
\text { - Level of } \\
\text { comfortableness } \\
\text { towards current } \\
\text { segregation practice. } \\
\text { - Difficulties faced by } \\
\text { workers towards } \\
\text { current segregation } \\
\text { system. } \\
\text { - Attitude towards } \\
\text { training and improving } \\
\text { waste management. } \\
\text { - Employees' } \\
\text { perception towards } \\
\text { various treatment } \\
\text { technologies. }\end{array}$ \\
\hline $\begin{array}{c}\text { To choose the } \\
\text { best available } \\
\text { technology } \\
\text { for waste } \\
\text { treatment }\end{array}$ & $\begin{array}{l}\text { - Linear additive } \\
\text { model Multi criteria } \\
\text { decision analysis. }\end{array}$ & $\begin{array}{c}\text { - Selection of } \\
\text { technology }\end{array}$ \\
\hline
\end{tabular}


I. The waste management policies should focus more on waste minimization.

II. The health care workers perspective towards medical waste management is critical towards efficient segregation and waste minimization.

Also a multi criteria decision analysis is used to find out the best treatment technology.

\section{Participant observation}

Participant's observation is useful for understanding the waste disposal process being carried out at different hospitals. The observation will also help to create needful relations with the staff and facilitate the research process. Series of site visits in Anand and nearby areas were made to collect data by observing and talking to people. The present research was conducted during 2016 - 2018. During the site visits, it was noted that attitude of health care workers towards waste segregation is really important in medical waste management. The whole process was observed and recorded.

\section{Questionnaire survey about the waste management practices of staff}

Questionnaire surveys are the best method to collect primary data from different workers associated with medical waste disposal [4]. The questionnaire survey questions were formulated in such a way that they aimed at understanding workers general knowledge about medical waste in terms of components, hazards and diseases that could be transmitted through improper management of medical wastes. The questionnaire was designed in such a way that it can provide general information about the hospital staff along with their knowledge about medical waste and their concern regarding the waste disposal-training program.

\section{Sampling and revising}

The sampling size was determined in such a way that it targets maximum people associated with the waste disposal in the hospitals. Since doctors and paramedical staff were very less associated with the waste disposal their number was kept on a smaller scale, while the nurses and ancillary workers who were maximally associated with the waste disposal of hospitals were surveyed maximally. The ratio decided was 1:7 for doctors to nurses and ancillary workers. The doctors and paramedical staff were surveyed just to check their concern towards the waste disposal of the hospitals.

\section{Analysing the result}

Along with the questionnaire survey, the participants were also asked about the other problems they faced, coordination problems within the various departments and suggestions to improve the medical waste management at the hospital. Some of them were asked questions based on the answers they gave in the survey.

\section{RESULTS AND DISCUSSION}

\section{Primary data analysis medical waste management policy at hospitals}

Hospital staff should be given regular vaccinations, especially the waste handlers. It is mandatory to keep waste category wise and day/date wise records while submitting the annual report to the state pollution control. This practice helps to upgrade the system and evaluate the performance of employees. Waste management committee should be formed and the body should work actively. Medical superintendent should be chairperson and nursing superintendent should actively support him to function effectively [5]. 


\section{Segregation of the medical waste}

The policy includes the segregation of the medical waste as follows (Table 2).

Table 2. Segregation of the medical waste

\begin{tabular}{|c|c|c|}
\hline $\begin{array}{c}\text { Colour } \\
\text { coding }\end{array}$ & $\begin{array}{c}\text { Type of container } \\
\text { according to waste } \\
\text { category }\end{array}$ & Treatment options \\
\hline Yellow & $\begin{array}{c}\text { Plastic bag Cat. 1, } \\
\text { Cat. 2, Cat. 3, Cat. } \\
6 .\end{array}$ & Incineration/deep burial \\
\hline Red & $\begin{array}{c}\text { Disinfected } \\
\text { container/plastic } \\
\text { bag Cat. 3, Cat. 6, } \\
\text { Cat.7. }\end{array}$ & $\begin{array}{c}\text { Autoclaving/Microwaving/ } \\
\text { Chemical Treatment }\end{array}$ \\
\hline Blue/White & $\begin{array}{c}\text { Plastic bag/puncture } \\
\text { proof container Cat. } \\
\text { 4, Cat. 7. }\end{array}$ & $\begin{array}{c}\text { Autoclaving/Microwaving/ } \\
\text { Chemical Treatment and } \\
\text { Destruction/shredding }\end{array}$ \\
\hline Black & $\begin{array}{c}\text { Plastic bag Cat. 5 } \\
\text { and Cat. 9 and Cat. } \\
10 .\end{array}$ & Disposal in secured landfill \\
\hline
\end{tabular}

\section{Details of medical waste generated at hospitals}

Details of medical waste generated at hospitals are presented in Figure 1.

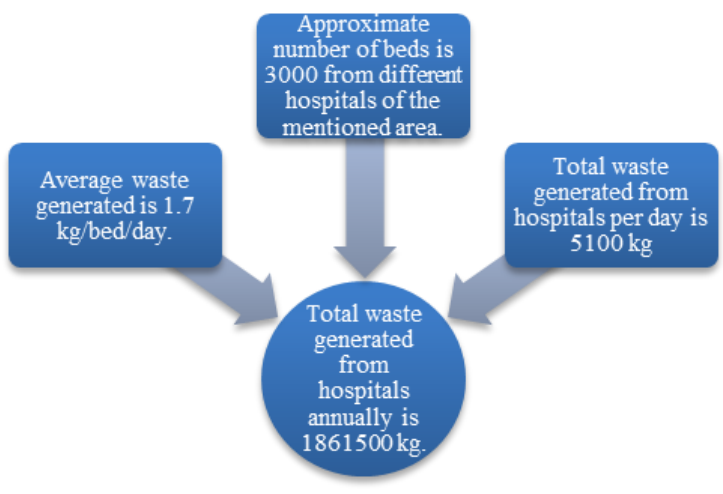

Figure 1. Details of medical waste generated at hospitals

\section{Greenhouse gases emissions from transportation of medical waste}

The 2010 guidelines prepared by DEFRA (Department for Environment, Food and Rural Affairs)/DECC (Department of Energy and Climate Change) regarding GHG conversion factors for company reporting [6] are used to find the data on the greenhouse gases emissions from the transportation of medical waste (Figure 2).

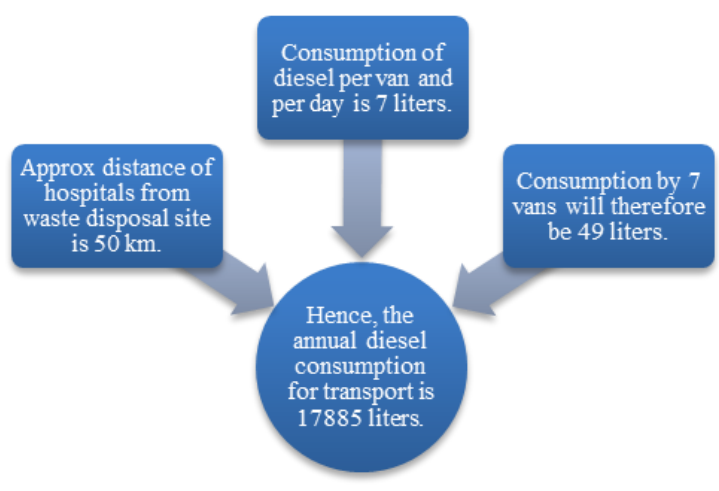

Figure 2. Annual diesel consumption for transport

Total $\mathrm{CO}_{2}$ emission per day and per van $22.2509 \mathrm{~kg}$ (Table 3).

Total $\mathrm{CO}_{2}$ emission for 7 vans $-155.7563 \mathrm{~kg}$.

Total $\mathrm{CO}_{2}$ emitted annually - $56851.0495 \mathrm{~kg}$.

Table 3. GHG emissions from transportation of medical waste

\begin{tabular}{|c|c|c|c|}
\hline $\begin{array}{c}\text { Type of } \\
\text { emissions }\end{array}$ & $\begin{array}{c}\text { Conversion } \\
\text { factors (CF) }\end{array}$ & $\begin{array}{c}\text { Units of } \\
\text { diesel } \\
\text { (liter) }\end{array}$ & $\begin{array}{c}\text { Resulting } \\
\text { emissions in } \\
\mathrm{kg} \mathrm{CO}= \\
\mathrm{CF} \text { x units }\end{array}$ \\
\hline $\mathrm{CO}_{2}$ & 2.6413 & 7 & 18.4891 \\
\hline $\mathrm{CH}_{4}$ & 0.0015 & 7 & 0.0105 \\
\hline $\mathrm{N}_{2} \mathrm{O}$ & 0.0292 & 7 & 0.2044 \\
\hline $\begin{array}{c}\text { Indirect } \\
\text { emissions }\end{array}$ & 0.5067 & 7 & 3.5469 \\
\hline \multicolumn{3}{|c|}{ Total emissions } & 22.2509 \\
\hline
\end{tabular}

Perception about the components of medical waste

Table 4 shows the awareness of various groups of people associated with waste disposal. The doctors considered every component as medical waste as their view was that everything generated from hospital contains pathogens and hence should be treated as medical waste. In this case opinion of nurses and other ancillary worker was different as hardly $15 \%$ of them considered paper boxes as medical waste. This shows their lack of concern towards the medical waste disposal, which increases the risk of infection being spread. 
Table 4. Components of medical waste

\begin{tabular}{|c|c|c|c|c|c|c|c|c|}
\hline \multirow{2}{*}{} & \multicolumn{2}{|c|}{ Doctors } & \multicolumn{2}{c|}{ Nurses } & \multicolumn{2}{c|}{$\begin{array}{c}\text { Ancillary } \\
\text { workers }\end{array}$} & \multicolumn{2}{c|}{ Paramedical staff } \\
\cline { 2 - 9 } & Yes & No & Yes & No & Yes & No & Yes & No \\
\hline Paper, boxes & $100 \%$ & $0 \%$ & $11 \%$ & $89 \%$ & $16 \%$ & $84 \%$ & $43 \%$ & $57 \%$ \\
\hline $\begin{array}{c}\text { Dressing cotton, } \\
\text { plasters }\end{array}$ & $100 \%$ & $0 \%$ & $85 \%$ & $15 \%$ & $87 \%$ & $13 \%$ & $98 \%$ & $2 \%$ \\
\hline Chemicals & $100 \%$ & $0 \%$ & $70 \%$ & $30 \%$ & $83 \%$ & $17 \%$ & $67 \%$ & $33 \%$ \\
\hline Pathology materials & $100 \%$ & $0 \%$ & $100 \%$ & $0 \%$ & $100 \%$ & $0 \%$ & $100 \%$ & $0 \%$ \\
\hline Body fluids & $100 \%$ & $0 \%$ & $100 \%$ & $0 \%$ & $100 \%$ & $0 \%$ & $100 \%$ & $0 \%$ \\
\hline $\begin{array}{c}\text { Pressurized } \\
\text { containers }\end{array}$ & $100 \%$ & $0 \%$ & $55 \%$ & $45 \%$ & $53 \%$ & $47 \%$ & & \\
\hline $\begin{array}{c}\text { Waste generated } \\
\text { from kitchen }\end{array}$ & $100 \%$ & $0 \%$ & $25 \%$ & $75 \%$ & $21 \%$ & $79 \%$ & & \\
\hline $\begin{array}{c}\text { Used syringes, } \\
\text { Injections etc. }\end{array}$ & $100 \%$ & $0 \%$ & $95 \%$ & $5 \%$ & $100 \%$ & $0 \%$ & $100 \%$ & $0 \%$ \\
\hline Used plastic bottles & $100 \%$ & $0 \%$ & $90 \%$ & $10 \%$ & $79 \%$ & $21 \%$ & & \\
\hline
\end{tabular}

\section{Hazardous impact of various components on environment}

From the Figure 3 it can be seen that the staff is not fully aware and still needs some proper counselling regarding the harmful impact of various constituents of medical waste on the environment.

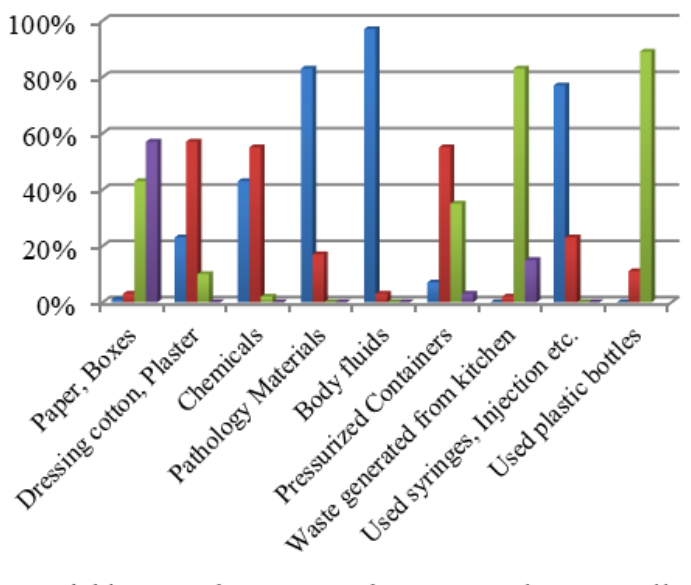

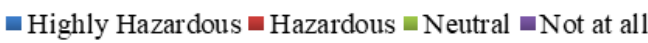

Figure 3. Hazardous impact of various components on environment

\section{Employees' perception towards current waste management practice}

All the workers are comfortable with the present color-coding system of disposal of waste and think that the present color-coding system needs no improvement. From the survey, it was found that $99 \%$ of the workers were comfortable with the present colorcoding system and consider it as user friendly. On further survey it was found that majority of the workers consider that the chance of waste going into the wrong bin is very frequent and they accepted that they put the waste in the wrong bin. Only about $5 \%$ of the workers believed that they never put the waste in the wrong bin. This information is shown in Figure 4.

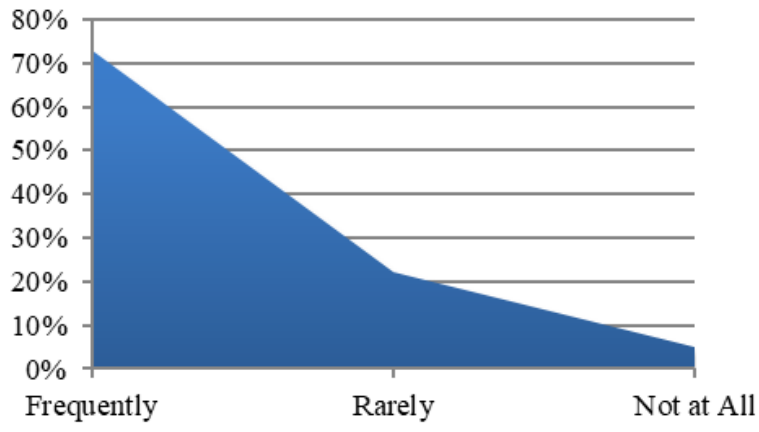

Figure 4. Frequency of workers putting the waste in the wrong bin

\section{Reasons for the waste going in the wrong bins}

Upon asking about various reasons for the waste going in the wrong bins and ranking 
them, the primary reason was found to be the lack of proper description on the bin, as indicated by $50 \%$ of the staff. The secondary reason was the lack of appropriate knowledge and hence it is necessary to give proper counselling to the staff regarding the knowledge about the waste disposal. Inappropriate location of the bin was ranked second and third as the reason for putting the waste in the wrong bin, and hence the bins should be placed as felt convenient by the staff concerned with the waste disposal (Figure 5).

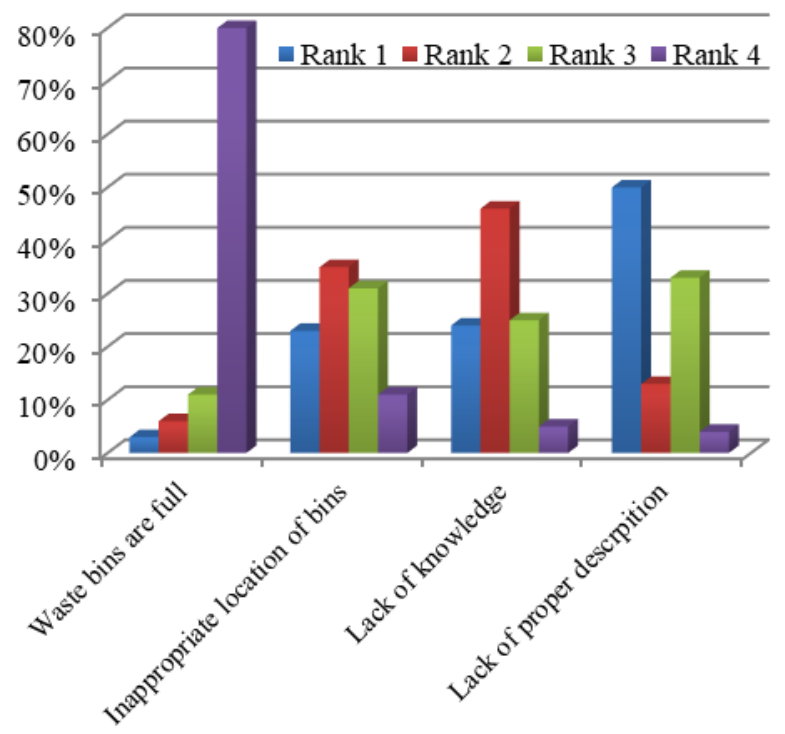

Figure 5. Reasons for the waste going in the wrong bins

Furthermore, when asked whether they react by informing the concerned person that they put the waste in the wrong bin, it was found that $94 \%$ of the workers did not inform the concerned person, which causes problems during segregation by the waste disposal team; if proper counselling were given to all staff and if they informed the concerned team, such problems could be avoided at later stages and proper and effective waste disposal could be achieved.

\section{Lack of knowledge among the staff regarding the proper disposal of waste}

Also, upon asking when the waste disposal bins should be sealed, quite varied results were obtained. Only $30 \%$ of the staff was aware that the bins should be sealed when they are $3 / 4$ full, according to the biomedical waste management and handling laws framed by Ministry of Environment and Forests (MoEF). This shows the lack of knowledge among the hospital staff regarding the proper disposal of waste and the guidelines issued by MoEF.

\section{Importance of the waste disposal training programs}

It was found that none of the staff has ever attended any waste disposal-training programs. This shows their eagerness to attend the waste disposal-training program if they are held in the hospital every year (Figure 6).

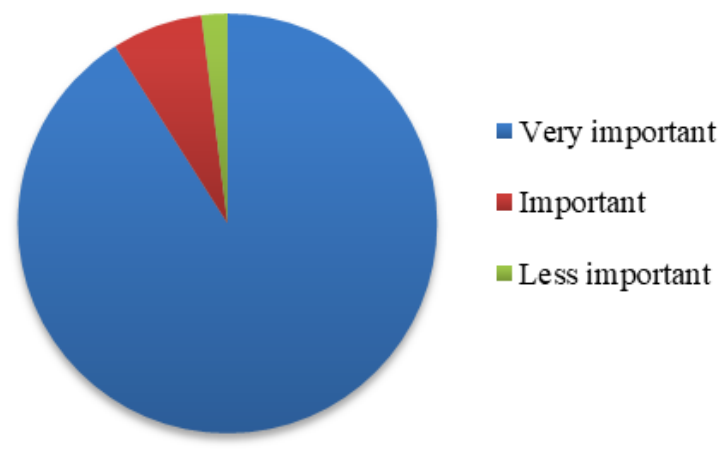

Figure 6. Responses to the importance of the waste disposal training programs

\section{CONCLUSION}

On a concluding note, if proper balance is maintained between proper waste disposals and sustainable discarding of the waste, along with risk minimization, the waste treatment costs can also be cut down. This can have a highly positive impact on the environment and the toxic substances being released in the environment can be reduced, and thus it can prove highly beneficial for the environment. The study has found that the city can benefit both environmentally and economically by improving the medical waste management at different hospitals. The study shows that the main reasons for the waste going in the wrong bin are lack of proper description or marking 
on the bins, lack of knowledge regarding the present color-coding system, inappropriate location of the bins. In addition, the study shows that a lot depends on the perspective of the health care workers, especially in the process of waste segregation. The study strongly supports the argument that the carbon emissions can be reduced by the proper management of medical waste. The amount of medical waste can be reduced up to $50 \%$ of the current generation pattern. An on-site treatment can avoid the unnecessary transport of hazardous waste. On the final note, an effective waste management program geared to waste minimization, coupled with treatment technology within the vicinity of the city, will help the hospitals to move towards sustainability.

\section{REFERENCES}

[1] E. Shinee, A. Gombojav, A. Nishimura, N. Hamajima, K. Ito, Healthcare waste management in the capital city of Mongolia, Waste Management 28(2008) 2, 435-441.

[2] S. Gopalakrishnan, R. Murali, Hospital Waste Management, Indian Journal of Community Health (1999) 4, 91-94.

[3] WHO, 2008, Reducing the carbon foot print at the health care sector, http://www.who.int/world-healthday/toolkit/dyk-whd2008_annex2.pdf, Accessed: September 4, 2014.

[4] E. McColl, A. Jacoby, L. Thomas, J. Soutter, C. Bamford, N. Steen, R. Thomas, E. Harvey, A. Garratt, J. Bond, Design and use of questionnaires: a review of best practice applicable to surveys of health service staff and patients, Health Technology Assessment 5(2001) 31, 1-256.

[5] A. Chatterjee, How to Segregate Biomedical Waste, https://aashim.wordpress.com/2012/03/0 3/how-to-segregate-biomedical-waste/, Accessed: September 4, 2014.

[6] A. Graikos, E. Voudrias, A. Papazachariou, N. Iosifidis, M.
Kalpakidou, Composition and production rate of medical waste from a small producer in Greece, Waste Management 30(2010) 8-9, 1683-1689. 